\title{
Development of School Culture as Initial Orientation Strengthening Character Education for Primary School Students
}

\author{
Maria Goreti ${ }^{1}$, Rini Kristiantari ${ }^{2}$ \\ \{rini_bali@yahoo.co.id ${ }^{1}$ \} \\ Universitas Pendidikan Ganesha, Indonesia
}

\begin{abstract}
Strengthening Character Education is the foundation of national education in students which aims to develop empathy, friendliness, and optimistic behaviors in accordance with the philosophy of the Pancasila life. This study aims at developing a school culture which acts as the initial orientation for character education. This research uses R\&D design methodology. Data used were principals and elementary school teachers in Denpasar City. Development data which is a reflection of the school's vision and mission was collected through documentation, interviews, and group discussions. The data was analyzed using the qualitative description method. The results of the study indicate that the school's vision and mission are valid and feasible and should be applied as a reference in implementing good character values in the school.
\end{abstract}

Keywords: School Culture Development, Strengthening Character Education

\section{Introduction}

Since the inception of the millennial age, and technological era, shifting the mindset and passion of the younger generation is becoming challenging. It is becoming tasking to foster the mentality of the current generation with that of the previous. The challenges faced by this generation are associated with ethics, character, and understanding of its culture. The current 21 st century will certainly bring change in its own dynamics in line with this era. The history of the present generation must certainly be beautified, and properly directed to remain closer to the national identity, tradition and nationalism.

Technology, which happens to be a part of the younger generation, must be optimized. It would be ironic, to drag this current generation into negativity because they are only victims of technology. The young generation must be formed and nurtured to be smart and effective in using technology. However, care should be taken to avoid the technological developments to keep them away from the traditions of the world of tradition which happens to be among the inspiration for their character formation.

Currently, learning efforts to thwart the current generation of educators is strategic. For this reason an educator must be professional not only in disciplines, but also in building themselves as role models. Today's teachers must create innovate learning techniques. They must be ready to face 
the challenges of seeking for new ways to teach students. It is important to avoid boring them and to remain supportive throughout the learning process. The creative power of the teacher will make the transfer of knowledge and behavior run naturally, in such a way that respect for that person is maintained (Syam, 2012).

In this current era of global education it is becoming increasingly important to ensure students have good learning and innovation skills. In addition, students it will ensure that students are skilled in using information technology and media, and can work and survive independently using skills. Life and career skills comprises of flexibility and adaptability, initiative and self-regulation, interactivity and culture, productivity and accountability, and leadership and responsibility. Learning and innovation skills include critical thinking, creativity, and innovation. Information technology and media skills consist of information, media and ICT literacy (Sahid, 2007)

No matter how much innovation is in learning, the teacher must still be able to set an example for his students. Teacher behavior and mentality will be a reference for students. In relation to the formation of 21 st century generation characters, teachers and learning components including school culture and society must build strong communication to overcome learning problems (Zuchdi, 2010). Don't let communication barriers make our young generation grow according to with respect to their hobbies, and desires without adequately controlling them.

One important thing that must be maintained is to grow a love for reading. The literacy movement which is currently one of the strategic education agendas must be optimized as it aids students to keep reading and broadening their knowledge, thereby, increasing their cognitive level. It is important to realize that in the 21 st century learning the role of teachers in production, creativity, innovation and effectively can be done by strengthening integrated attitudes, skills and knowledge. The use of appropriate and continuous learning methods aids in building a positive school culture expected to encourage students to make better observations, ask intelligent questions, and reason and communicate effectively. As a result of this, 21 st century children are expected to be trained early. In addition, character growth must be carried out continuously, and integrated in learning activities so that students will properly grow through the school culture and environment. This is in line with the slogan that states that a great nation is a nation that has high knowledge, good skills, and strong character (Althof \& Berkowitz, 2006, 2013).

The expected conditions according to the above explanation are currently quite difficult to find in elementary schools situated in the city of Denpasar. This is because there are insufficient insights held by educators, especially those who are at the basic level, in applying the theories they obtain. Developing character values and national culture will only be effective if developed in the classroom, which happens to be the sole reason why this research was conducted.

\section{Research focus}

This research focuses on how the school culture contained in the vision and mission was developed as an initial orientation for strengthening character education for elementary school students in the city of Denpasar. 


\section{Method}

The design of this study is research and development ( $\&$ \& $)$ research (Gall, Gall, \& Borg, 2007) which has been modified as follows:

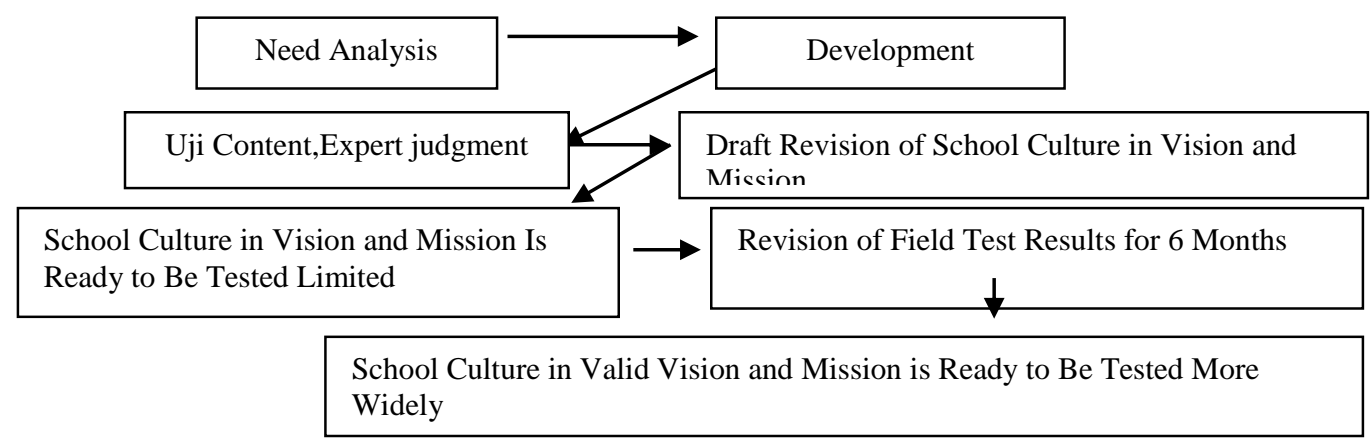

Fig 1. Stages of Research According to Borg and Gall (2007)

The data of this study are (1) activities that support the growth of character values contained in the vision and mission (2) implementation of school culture in the form of positive activities. The data sources of this study are principals and elementary school teachers who study in Denpasar City. Data was collected through (1) observation, (2) interviews, (3) discussions, and (4) document studies. The collected data was then analyzed using descriptive qualitative method .This research data can be accessed at http://osf.io/k2y 74 .

\section{Results}

The findings of this study refers to the focus of the research formulated in the introductory section, which is related to school culture and implemented in the form of positive activities to foster national character values. The vision and mission associate with positive behavior in schools are presented below.

\section{Vision and mission \\ SD Negeri 3 Pedungan}

\section{VISION}

Preparing Cultured, Smart, Skilled, good character, with knowledge of science and technology, Based on Faith MISSION

a. Increase cultural insight and creativity through guidance and practice.

b. Improve the quality and effectiveness of PBM through student centered learning using multimethods and media, using PAKEM or Contectual Teaching Learning (CTL) aimed at developing an oriented life, skills, and guidance and counseling services.

c. Creating a conducive, safe, comfortable school environment for the effectiveness of all educational activities inside and outside the school

d. Develop a spirit of achievement and create a competitive culture that is honest and supportive for all school members.

e. Develop appreciative and practical teachings so that people who are loyal, obedient and noble areawakened. 


\section{VISIION AND MISION SEKOLAH DASAR NEGERI 12 DAUH PURI}

VISION

"Realization of students who excel in achievement, godliness, Insights and Culture"

MISSION

1. Behavior Development in Accordance with Pancasila Philosophy and Religion respectively

2. Developing Intellectual Children by Implementing the Teaching and Learning Process which

is Active, Creative, Effective and Fun

3. Developing a training in accordance with Local Content

4. Ensuring that Students Receive Good Learning And

Achieve outstanding achievements in the fields of Academics, Arts and

Culture

5. Developing Good Cooperation with religious, traditional, and community leaders.

6. Trying to Unite Schools with Communities So They Become One

From the above listed examples, it can be seen that the norms are used as guidelines and bases for thinking, speaking, and behaving well in and outside the school premesis, starting from the principal, teachers, students, and the community. Through the vision and mission developed, the five main values of the characters targeted by the national mental revolution movement can be developed. These values are religious, nationalist, independent, cooperative, and integrity values.

Based on the results of observations and interviews regarding the development of the school's vision and mission, a culture of good practice is carried out with the aim of actualizing a discipline, honest, and friendly culture. The following presentation is an example of good practice that is sought and implemented in schools: (1) activities carried out to clean classrooms in groups before entering the class, praying together, singing national songs and other social activities should be carried out before starting classroom learning (2) flag ceremony activities should be conducted every Monday as a form of building nationalist values and integrity of the Indonesian society, (3) cooperation activities with school and the surrounding communities on the first Friday of each month. The community service should be carrid out in and outside the school yard, as well as in the various water channels (4) the culture of other schools that are also built in the selected primary school is to pray together at HariPurnama and Tilem, culture queuing should be adopted for those that wish to go to the bathroom or the school canteen. 


\section{Discussion}

Schools are one of the educational institutions given the task of delivering the objectives of national education. In carrying out its role, schools must be managed properly so that they can realize educational objectives that have been formulated optimally. Unprofessional school management can hinder the ongoing education process, thereby, hampering the steps in carrying out its formal functions.

In order for school management to function properly, a strategic plan is needed to control the organization (school) effectively and efficiently, so that the goals and objectives are achieved. Strategic planning is the basis for schools to carry out the education process. Strategic planning is intended in every school.

According to (Calam \& Qurniati, 2016) vision is a series of sentences that express the ideals or dreams of an organization to achieve future goals. Vision is a statement of wanting to be in a school/organization. Vision is also very important for organizations to ensure sustainability and long-term success. In the organizational vision future values, aspirations and needs of the organization is revealed (R. JatiNurcahyo, 2015). The vision formulated together will build a good work commitment to achieve goals.

The existence of a vision gives rise to a mission. This realization will make the school to be able to produce quality and brilliant students. . Mission is something real to aim for and can also provide guidance on how to achieve Vision. Therefore, in preparing the vision and mission, the school needs to work with various parties, so that the formulated traits can really be used as a guide, and reference, to achieve set goals. What is contained in the vision and mission must be carried out in the daily life of the school community.

As explained in the introduction, the Character Education Strengthening movement initiated by the government places character as the deepest dimension of education that fosters and presents noble values. In the academic text the Development of Character Education of the Ministry of National Education (Kemdikbud.2017) formulates 18 character values that can be built and grow in the young generation of the Indonesian nation. Furthermore, eighteen character values are classified into four working groups in an effort to succeed the national character education movement, namely: (1) spiritual and emotional development, (2) intellectual development, (3) sports and kinesthetic (physical and kinesthetic development), and (4) feelings and intentions (affective development and creativity). The four character groups have core character elements.

If we pay close attention to the meaning contained in the vision and mission compiled by elementary schools, this research is almost not different from the values that inherent therein. The national mental revolution movement launched by the government aims to build a young generation with a brilliant character towards the emergence of a golden generation for the people of Indonesia.In this millennium and unlimited information era, it is impossible to create a brilliant generation equipped with a strong character foundation.

Building a school culture in line with the vision and mission is similar to supporting the joy of eight Indonesian Presidents. This is because it is in line with the mandate contained in the philosophy of Pancasila life, namely piety, humanity, unity, mutual cooperation, and social justice. 


\section{Conclusion}

School culture is the values that are held firmly by the school community obtained from schools and its surrounding environment. It is a reflection of our daily life that characterizes a school (culture). School culture can be made by habituating good habits that will produce a positive culture, and vice versa. It is undeniable that building and applying a positive school culture is inseparable from the important role of school leaders. The principal becomes a decisive part of the realization of a good school culture on the basis of the policies implemented, the program being proclaimed, as well as clear targets and achievement strategies, outlined in the school's vision and mission. From the submitted disclosures the following can be concluded: (a) in realizing good quality schools, plans should be made and implemented. In this case the school needs to formulate an integrated vision, mission, goals and program strategically (b) Strategic planning is a guide for schools in implementing the education process at the respective education unit level. The formulation will determine the desired future picture of the school, because it will be integrated in strategic planning making it a reference in carrying out its activities as an educational institution. Strategies carried out to create a school culture include: 1) implementing well-planned programs and clear achievement strategies, 2) making changes in the mindset of all stakeholders, 3) providing good examples, 4) instilling character values and 5) creating optimal carrying capacity.

\section{Reference}

[1] Althof, W., \& Berkowitz, M. W. (2013). Character and civic education as a source of moral motivation. In Handbook of Moral Motivation: Theories, Models, Applications (pp. 567-583). https://doi.org/10.1007/978-94-6209-275-4

[2] Calam, A., \& Qurniati, A. (2016). Merumuskan Visi Dan Misi Lembaga Pendidikan. Jurnal Ilmiah SAINTIKOM. https://doi.org/10.1109/RCIS.2010.5507391

[3] Gall, M. D., Gall, J. P., \& Borg, W. R. (2007). An Introduction to Educational Design Research. East, 129. Retrieved from www.slo.nl/organisatie/international/publications

[4] R. Jati Nurcahyo. (2015). Keterkaitan visi, misi dan values terhadap kinerja karyawan perusahaan kulit "Dwi Jaya." Jurnal Khasanah Ilmu.

[5] Rini A 2019 Dataset Development of School Culture as Initial Orientation Strengthening Character Education for Primary School Students. Retrieved from osf.io/k2y74

[6] Sahid. (2007). Pengembangan Media Pembelajaran Berbasis ICT. Pendidikan Matematika FMIPA UNY, 1-16.

[7] Syam, A. (2012). KEPEMIMPINAN PENDIDIKAN YANG INOVATIF. Al-Ta Lim, 19(2), 151. https://doi.org/10.15548/jt.v19i2.16

[8] Zuchdi, D. (2010). Pengembangan model pendidikan karakter terintegrasi dalam pembelajaran bidang studi di sekolah dasar. Cakrawala Pendidikan, 29(1), 1-12. https://doi.org/10.21831/cp.v1i3.224 